\title{
Measuring global competition
}

\author{
Victor Camlek \\ Thomson Reuters IP \& Science, Philadelphia, PA 19130, USA
}

\begin{abstract}
The goal of this paper is to describe selected leading indicators of global competitiveness. This will be accomplished by reviewing several selected sources that focus on various metrics. The reported data was determined to be the most recent at the time of a presentation of this material to NFAIS in February 2012. The goal of this paper is to be objective and informational. Each of the selected indicators will be described in a high-level with a brief review of significant results. This paper will illustrate that there is no one "global leader" across the various categories that are reviewed. The data will show that well established economies, such as the US and EU countries continued to maintain significant levels of funding and achievement, yet these data will also demonstrate how leading positions are being eroded by rapid advances among emerging economies led by China. The Regionally Developing Economies (RDEs) are visibly increasing their positions in various rankings. The data also shows that some of the smaller, yet more established economies, such as Switzerland achieved top positions when a variety of input and output pillars and sub-pillars are utilized within the assessment methodology. Switzerland has long been considered to be a wealthy economy. Finally, the presentation will review, at a high-level the status of STM publishing within an increasingly global market. The paper will summarize recent activities and point to selected RDE markets where local STM market forces are emerging, either in the form of incumbent global publishers who are establishing presence via local partnerships or countryspecific publishing operations. In addition, the emerging markets feature notable in-country participants.
\end{abstract}

Keywords: Competition, global competition, global competitiveness, GDP, BRIC, innovation, economic performance, STM publishers, China, Brazil, RDE, India, Japan, USA, education

\section{Introduction}

The world is becoming increasingly competitive as established economies are joined by emerging economies that are growing at a rapid pace. As global competition increases there are a number of authoritative sources that measure the current status of competition and deliver a variety of ratings and rankings. The goal of this presentation is to provide a selected sampling of the various sources used to measure global competitiveness (GC) and to review representative findings at a high level. This presentation will provide an overview of metrics that will come from a variety of perspectives including:

- Economic performance;

- Global innovation;

- Financial performance;

- Research and development spending;

- Patent and filing statistics;

- Education trends;

- Scholarly research bibliometrics.

Global competitiveness involves a variety of metrics aimed at assessing the performance of countries and regions. Generally the assessments are presented by expert organizations that focus on specific categories, such as Global Innovation, or a variety of rankings that result in sub indices. The results are presented in a ranking that may be compared with past data to evaluate performance trends and changes. 
In some cases more than one organization will report on the same or a similar metric. It is up to the users of these data to determine which source will be used for a purpose that could include a range of activities such as: investment strategies, strategic planning, M\&A, sales planning, product development or target market evaluation. It is important to note that the results are not based on an on-going competition, such as a contest or sporting event. These data do not represent winners or losers. Rather, they indicate how when various performance criteria are weighed and compared there will be a range of capabilities which indicates that potential for future success rather than a victory in a one-time contest.

\section{Economic performance}

There are numerous indicators of economic performance. However, one of the most visible measures we hear about on a frequent basis is GDP or "Gross Domestic Product". GDP refers to the value of a country's overall output of goods and services [3]. There are several ways to measure GDP (real GDP, Nominal GDP and Purchasing Power Parity). For the purpose of this presentation we have utilized Purchasing Power Parity or PPP GDP. This is because GDP based on purchasing parity is a metric that enables a good formula for comparison. PPP GDP adjusts exchange rates so that an identical good in different countries has the same price when expressed in the same currency. There are a variety of sources that offer GDP PPP summaries and forecasts including: The International Monetary Fund Database, The World Bank and The US CIA (Central Intelligence Agency) World Fact Book. Each of these sources is available for free over The Internet.

One final important point, GDP in any of its forms is a measure of output and relative growth or decline; it is not a measure of wealth. There are additional metrics that focus on income data that offer a better view of wealth or actual purchasing power for new goods and services.

According to each of the sources mentioned, the US continues to lead the world in PPP GDP. China has moved into a number two position within the past decade. In fact, analysts have been forecasting for years that China will eventually rise to the number one spot and assume global leadership in terms of GDP.

Table 1 illustrates a view of the leading nations in terms of PPP GDP that ranges from 2007 to a forecast period out to 2016. It is clear from the table that the top performers include a mix of established economies (US, Japan, Germany, UK and France) along with a first wave of regionally developing economies (RDE's) known as the "BRICS's" including Brazil, The Russian Federation, India and China. The BRIC economies have become well known as fast growing nations that are changing the nature of global commerce. According to this forecast China will overtake the US and claim the top spot in 2016. This is not a new development. There have been a number of forecasts indicating that China would eventually rise to the top spot, although this one forecasts the shift in leadership much sooner than the original forecasts.

Impact: GDP offers an important way to determine the economic production on an annual basis as well as a way to determine trending over time. From the data presented in Table 1 it is very clear that the established economies are losing ground in terms of annual production. The trend has been occurring over a reasonable period of time with little sign of changing trajectories.

\section{Global innovation}

There is intense interest on the part of nations and global companies to innovate. In the simplest terms, innovation refers to the transference of an idea or an invention into a product or service that has commer- 
Table 1

Global economies based on GDP PPP

- Chart displays growth in China's GDP heading toward global leadership

- GDP is a valid economic measurement but it does not measure the distribution wealth

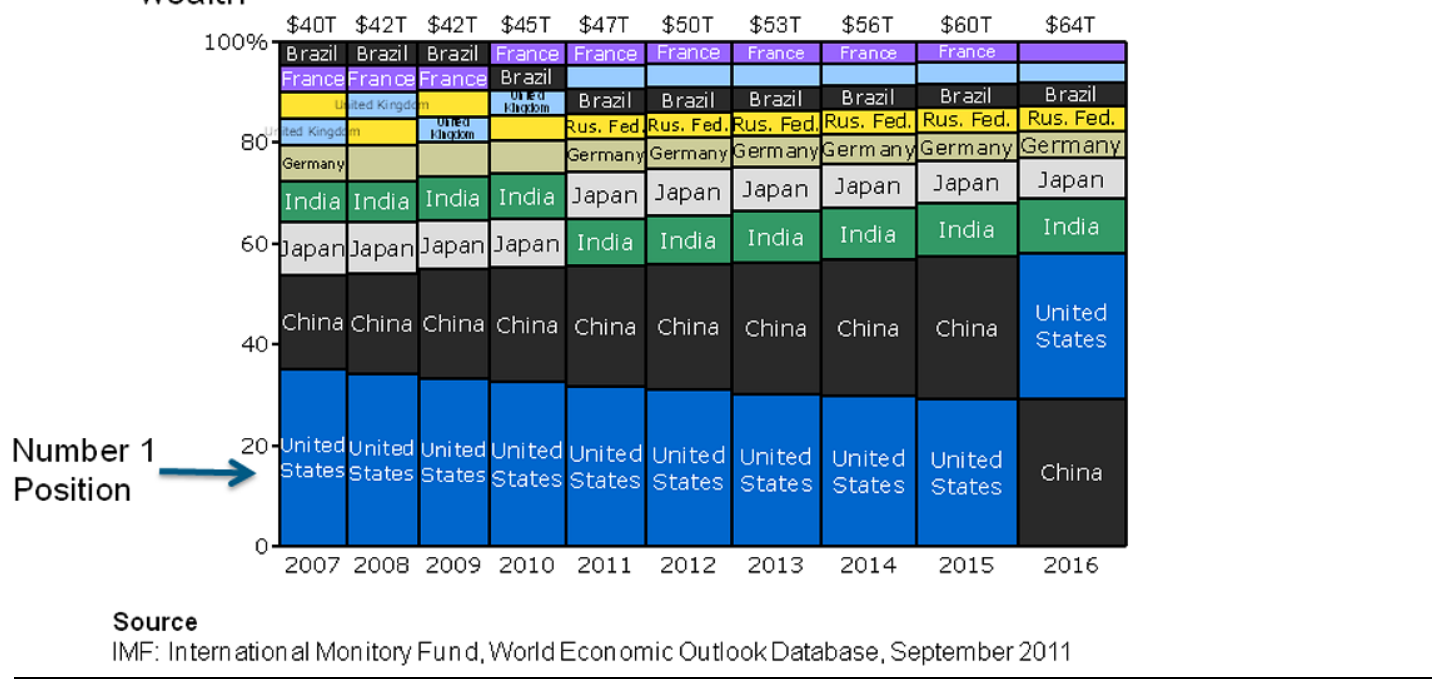

Note: Colors are visible in the online version of the article; http://dx.doi.org/10.3233/ISU-2012-0636.

cial applications whereby consumers will be willing to pay for it. The term is also used to describe new ways of doing ongoing tasks that are improvements in terms of the time and/or cost to perform various functions. There are various levels of innovation, including continuous development or revolutionary changes that quickly replace incumbent ways of doing things. For example, it is hard to remember life without The Internet, yet prior to the 1990s there was no easy way to access a ubiquitous online information network that featured information and social applications. Since its commercialization path that began around 1990 it is a safe to say that The Internet has disrupted the previous methods of information gathering. This "disruptive" innovation has impacted everything from day-to-day travel, news and information to the method and type of information sources readily available to scholars.

There are several sources that measure innovation. For the purpose of this presentation, "The Global Innovation Index (GII)" will be reviewed. The GII has become an annual publication since 2007 from INSEAD, "The Business School of the World". It offers a very detailed global analysis that ranks 125 countries based on a complex series of "pillars" and "sub-pillars". In 2011, INSEAD indicated that its knowledge partners included: Alcatel-Lucent, Booz and Company, the Confederation of Indian Industry, and the World Intellectual Property Office (WIPO) [9].

The GII provides a detailed commentary and summary of findings. Essentially the GII:

- Computes an average of scores across inputs pillars, or an enabling environment for innovation and output pillars that measure actual achievements in innovation.

- Five pillars constitute the Innovation Input Sub-Index, including: Institutions, Human capital and research, Infrastructure, Market sophistication and Business sophistication.

- The Innovation Output Sub-index is composed of two pillars: Scientific outputs that indicate actual achievement in innovation and Creative outputs. 
- The Innovation Efficiency Index is calculated as the ratio of the two Sub-indices. It examines how economies leverage their enabling environments to stimulate innovation results [9]. The Innovation Efficiency Index permits countries with lesser resources to score higher results based on the assessment of how well they take advantage of the resources that are in place.

According to the 2011 Index, Switzerland achieved first place in the overall 2011 GII rankings. This position represented a rise to the top from the 4th position Switzerland reached in 2010. According to the GII, Switzerland reached the top of the leader board based on its strong position in both the Input and Output Sub-indices. Interestingly the country did not top any individual pillar but it placed within the top 5 Input pillars (Institutions, Market sophistication and Business sophistication) and both Output Pillars (Scientific outputs and Creative outputs). Based on the aggregate view, the country emerged as the global leader [9].

Table 2 summarizes the overall GII: Innovation leaders.

Although Table 2 offers a summary of the overall GII leaders over the past three performance years there is a great deal more information, detail and assessments contained within the source document. Therefore, it should be explored more closely by anyone seeking to truly understand the methodology and results. The goal was to indicate the availability of this annual review as an authoritative source of competitiveness rating and ranking.

It is useful to point out an additional metric, The Innovation Efficiency Index. This interesting index covers those countries that achieve "more from lesser conditions" as well as those that lag behind because the methodology of the index results in a lower score when available resources are not utilized as much as they could be. The top 10 leaders within this metric included:

Table 2

Innovation leaders

\begin{tabular}{lccccc}
\hline Country & $\begin{array}{c}\text { Scale (0- } \\
\text { 100) }\end{array}$ & Income & 2011 & 2010 & 2009 \\
\hline Switzerland & 63.82 & $\mathrm{HI}$ & 1 & 4 & 7 \\
\hline Sweden & 62.12 & $\mathrm{HI}$ & 2 & 2 & 3 \\
Singapore & 59.64 & $\mathrm{HI}$ & 3 & 7 & 5 \\
\hline $\begin{array}{l}\text { Hong Kong } \\
\text { (SAR) China }\end{array}$ & 58.80 & $\mathrm{HI}$ & 4 & 3 & 12 \\
\hline Finland & 57.50 & $\mathrm{HI}$ & 5 & 6 & 13 \\
\hline Denmark & 56.96 & $\mathrm{HI}$ & 6 & 5 & 1 \\
\hline USA & 56.97 & $\mathrm{HI}$ & 7 & 11 & 11 \\
\hline Canada & 56.33 & $\mathrm{HI}$ & 8 & 12 & 10 \\
\hline Netherlands & 56.31 & $\mathrm{HI}$ & 9 & 8 & 4 \\
\hline UK & 55.96 & $\mathrm{HI}$ & 10 & 14 & \\
\hline
\end{tabular}

Source: Data from $2011 \mathrm{GI}$

Note: Colors are visible in the online version of the article; http://dx.doi.org/10.3233/ISU-2012-0636. 
- Côte d'Ivoire;

- Nigeria;

- China;

- Pakistan;

- Moldova;

- Sweden;

- Brazil;

- Argentina;

- India;

- Bangladesh.

Three BRIC economies (Brazil, India and China) are visible in this list. However, The Russian Federation appeared in the 52nd position.

Impact: The GII represents a detailed analysis based on numerous factors that indicates an annual ranking of innovation by various measures. To gain a more in-depth awareness of the report further study is recommended. A detailed review of the GII is necessary to truly understand how these rankings are influenced by a variety of factors including economic conditions and reported achievement. Also worth mentioning, there are several additional Innovation Indices from sources such as McKinsey, Booz \& Company, The Economist Intelligence Unit and the World Economic Forum.

\section{Global financial performance}

The World Economic Forum publishes an annual report entitled, "The Global Competitiveness Report". This document provides a detailed analysis based on 12 Pillars including: Institutions; Infrastructure; Macroeconomic environment; Health and Primary Education; Higher Education and Training; Goods Market Efficiency; Labor Market Efficiency; Financial Market Development; Technological Readiness; Market Size; Business Sophistication; and Innovation.

As indicated by Table 3, Switzerland tops the overall rankings. Singapore rose to the second position followed by northern and Western European countries that dominate the top 10. Japan remained in the top ten although it moved down to the number nine position from number 6 the previous year. The US continued to decline for the third year in a row, falling one or more place to the fifth position. This was largely due to macroeconomic vulnerabilities that continued to build. However, on a positive note, banks and financial institutions demonstrated a rebound during the 2011 for the first time since the financial crisis [23].

Germany maintained a strong position within the Eurozone. This result occurred despite declining by one position to sixth place in the overall rankings. Meanwhile, France dropped by three places to the number 18 position. Also of note, Greece challenged by economic problems, continued a recent trend by declining to the 90th spot [23].

The People's Republic of China led the developing economies. The country increased to the number 26 spot, an improvement of one position over the previous year. In this Index the other BRICs were further down in the rankings, including Brazil (53), India (56) and The Russian Federation (66). The Asian economies performed strongly led by Japan (9th) and Hong Kong SAR (11th) [23].

"The overall results illustrate that while competitiveness in advanced economies has stagnated over the past seven years, in many emerging markets it has improved, placing their growth on a more stable footing and mirroring the shift in economic activity from advanced to emerging economies" [23]. 
Table 3

Global competitiveness report

\begin{tabular}{|l|r|r|r|}
\hline Country & Score & 2011-2012 & 2010-2011 \\
\hline Switzerland & 5.74 & 1 & 1 \\
\hline Singapore & 5.63 & 2 & 3 \\
\hline Sweden & 5.61 & 3 & 2 \\
\hline Finland & 5,47 & 4 & 7 \\
\hline USA & 5.43 & 5 & 4 \\
\hline Germany & 5.41 & 6 & 5 \\
\hline Netherlands & 5.41 & 7 & 8 \\
\hline Denmark & 5.41 & 8 & 9 \\
\hline Japan & 5.40 & 9 & 6 \\
\hline UK & 5.39 & 10 & 12 \\
\hline
\end{tabular}

BRIC Rankings: China 26; Brazil 53; India 56; Russian Federation 66

Source: World Economic Forum Global Competitiveness Report 2011-12, c2011

Note: Colors are visible in the online version of the article; http://dx.doi.org/ 10.3233/ISU-2012-0636.

Impact: This study further illustrates that complicated multi-faceted assessments tend to favor the more established economies. Nordic countries such as Switzerland, Sweden, Finland and Denmark tend to perform well when various pillars and measures of efficiency are within the assessments methodology [23].

\section{Research \& Development (R\&D)}

Overall R\&D expenditure is measured by "GERD" or "Gross Domestic Expenditure on R\&D". This metric was introduced by the OECD in 2002 in the Frascati Manual [8] and measures the investment in R\&D from four economic sectors: business, university, government and non-profit [8].

Each year the Special Issue of $R \& D$ Magazine provides an annual review and forecast of R\&D [1]. Co-sponsored by the Magazine and Battelle, the special issue is based on an annual survey that measures various aspects of global R\&D. The 2012 issue reported the following headlines:

- US industry R\&D increased by $3.8 \%$ to reach $\$ 280$ billion.

- There was evidence of a "growing emphasis on basic research".

- Global R\&D spending is forecast to increase by 5.2\% to reach $\$ 1.4$ trillion.

- The survey revealed an increasing importance of R\&D return on investment (ROI).

- Numerous tables and text summarized R\&D trends by geography and industry [1].

The results from the latest $R \& D$ Magazine survey indicate that The Americas will lose the top position in terms of global share of R\&D investment by 2012. Summarizing the data on a regional basis, Asia's investment in R\&D is increasing. According to the survey, "most of the global funding growth is being driven by Asian economies, which are expected to increase by nearly $9 \%$ in 2012, while European R\&D will grow by about $3.5 \%$ and North American R\&D by $2.8 \%$ in $2012 \%$. 
In 2012 Asia is forecast to assume the top global share (36.7\%) moving it ahead of The Americas by 700 basis points. However, among individual nations, the US continues to have a high share $(31.1 \%$ in 2012) of Total Global R\&D Spending. Despite declines in share, US R\&D is forecast to spend $\$ 436$ billion on R\&D in 2012. The published forecast noted that although US Federal Government investment in R\&D is expected to decline in 2012, the R\&D spending on the part of US industry and academia are both forecast to increase. Despite visible declines in overall share of R\&D investment the report notes that the scale of the US R\&D investment remains very high. The report states, "R\&D growth in emerging economies has lowered the US share of global funding to about $31 \%$, although the US remains dominant in absolute terms, and annual increases in US R\&D still exceed the total budgets of most countries" [1].

$R \& D$ expenditure is another metric illustrating strong growth in China which became "the world's second largest $R \& D$ investor in 2011". This growth is expected to continue to be driven by China's increasing growth in GDP [1].

On a national basis, the top 10 countries in terms of GERD are:

1. US: $\$ 436.0 \mathrm{~B}$;

2. China: $\$ 198.9 B$;

3. Japan: $\$ 157.6 \mathrm{~B}$;

4. Germany: $\$ 90.6 \mathrm{~B}$;

5. South Korea: $\$ 56.4 \mathrm{~B}$;

6. France: $\$ 51.1 \mathrm{~B}$;

7. United Kingdom: $\$ 42.4 \mathrm{~B}$;

8. India: $\$ 41.3 \mathrm{~B}$;

9. Brazil: $\$ 30.0 \mathrm{~B}$;

10. Canada: $\$ 28.6 \mathrm{~B}$.

Impact: Several trends have emerged from this annual review:

- Emerging economies are increasing their global technological presence.

- Economic issues in established economies show signs of impacting their ability to support R\&D.

- Established economies are losing their unique "tech-opolies".

- Sustainability is becoming a competitive advantage.

- Energy has created new technology opportunities and hazards.

- Rapid technology innovation is creating a more knowledge-intensive world.

- Product and technology sourcing has created new techno-politico issues [1].

\section{Measuring trends in education}

There are numerous data points that track trends in education, such as number of degrees, University enrollments and International graduate school applications by discipline.

A review of a variety of performance data within education, derived from several studies indicated yielded the following insights:

- A trajectory that supports the argument that attainment of undergraduate and graduate degrees is increasing in emerging economies (Brazil, India, China) while US attainment appears less than 2000 , which currently appears as a peak year. However, based on full population the US continues to provide degrees to a substantial number of people [2].

- Significant growth in India and China [5]. 
- China now produces an equal or greater number of natural science and engineering graduates than the US [7].

According to the US National Science Foundation:

- The number of S\&E doctoral degrees awarded in China, Italy and the United States has risen steeply in recent years.

- Until 2006, the United States awarded the largest number of natural sciences and engineering doctoral degrees, but, in 2007, China surpassed the United States.

- In the United States, as well as in France, Germany, Italy, Spain, Switzerland and the United Kingdom, the largest numbers of S\&E doctoral degrees were awarded in the physical and biological sciences.

- The number of doctoral degrees awarded in S\&E stagnated or declined in many of these countries between 2000 and 2004, although that number increased in later years in Italy, Switzerland and the United States.

- In Asia, China was the largest producer of S\&E doctoral degrees. As China's capacity for advanced S\&E education increased, the number of S\&E doctorates awarded rose from about 2,700 in 1994 to almost 28,500 in 2008 , a substantially faster rate of growth when compared to the number of doctorates earned by Chinese citizens in the United States during the same period.

- The number of S\&E doctorates awarded in India, Japan, South Korea and Taiwan also rose from 1994 to 2008, but at a lower rate. In China, Japan, South Korea and Taiwan, more than half of S\&E doctorates were awarded in engineering. In India, almost three-quarters of the S\&E doctorates were awarded in the physical and biological sciences [20].

It is also important to note that within the overall US Science and Engineering data, the NSF reports that "About $60 \%$ of all foreign graduate students in the United States in 2010 were enrolled in S\&E fields, compared with $32 \%$ at the undergraduate level. Most of the growth in the number of foreign graduate students in S\&E between 2009 and 2010 occurred in engineering and computer sciences. India and China were the countries of origin for nearly two thirds of the foreign S\&E graduates in the United States in November 2010" [20].

Impact: Whereas economic and financial metrics are indicators of the recent and previous economic environment, the changing patterns within education are indicators of future strength. Based on the data reviewed it is safe to say that there are several indicators that point to increased global interest in Education. There remain high levels of educational attainment within established economies; however, it is also evident that China and other developing economies are increasing their educational footprints. For example, China has experienced a $4 \times$ growth in scientific and engineering degrees from 1997-2007. According to the National Science Board, "In terms of total researchers, the US and the EU experienced moderate annual growth of high-tech about scholarship of 3\% between 1995 and 2006 while growth in the Asia region outside Japan ranged from 7-11\%. China averaged nearly 9\% growth in 2006 annually in researchers, far outstripping any other countries. During this period the number of China's researchers nearly tripled, from just over half a million to more than 1.4 million, boosting its global share from $13 \%$ to 25\%". The US also has around 1.4 million researchers, which places China at a level playing field in overall numbers. It will be very important from a global perspective to track and pay heed to these patterns as the current trajectories could reshape the scientific markets in the future [20]. 
Table 4

Global patent data

Patents, trademarks and GDP annual growth rate (\%), 2009 and 2010

\begin{tabular}{|c|c|c|c|c|c|c|}
\hline \multirow[t]{2}{*}{ IP Offlice } & \multicolumn{2}{|c|}{ GDP } & \multicolumn{2}{|c|}{$\begin{array}{c}\text { Patent } \\
\text { applications }\end{array}$} & \multicolumn{2}{|c|}{$\begin{array}{l}\text { Trademark } \\
\text { applications }\end{array}$} \\
\hline & 2009 & 2010 & 2009 & 2010 & 2009 & 2010 \\
\hline World & -0.7 & 5.1 & -3.6 & 7.2 & -2.6 & 11.8 \\
\hline $\begin{array}{l}\text { Advanced } \\
\text { economies* }\end{array}$ & -3.7 & 3.1 & -5.4 & 3.7 & -9.5 & 4.0 \\
\hline $\begin{array}{l}\text { France, Germany } \\
\text { and the } \\
\text { United Kingdom* }\end{array}$ & -4.3 & 2.3 & -6.5 & 7.1 & -2.6 & 6.9 \\
\hline $\begin{array}{l}\text { United States of } \\
\text { America (US) }\end{array}$ & -3.5 & 3.0 & 0.0 & 7.5 & -10.1 & 5.0 \\
\hline Japan & .6 .3 & 4.0 & -10.8 & -1.1 & -8.1 & 11.1 \\
\hline Republic of Korea & a 0.3 & 6.2 & -4.2 & 4.0 & -10.1 & -5.3 \\
\hline China & 9.2 & 10.3 & 8.5 & 24.3 & 19.1 & 29.8 \\
\hline
\end{tabular}

-Worldwide filings rebounded in 2010

- China and the US accounted for the majority of worldwide growth (4/5ths) China IP growth more than doubled GDP growth

- Patent growth in Europe represented by France, Germany and the UK plus applications from the EPO far exceeded GDP growth rate

- Japan growth rate more than doubled GDP

- Republic of Korea only reported office where GDP growth exceeded patent growth

Source: MPO 2011 World Intellectual Property Indicators http://Mmw wipo int/export'siteshmm/freepublications/en/intpropertv/941/wipo pub 941 2011.pdf

Note: Colors are visible in the online version of the article; http://dx.doi.org/10.3233/ISU-2012-0636.

\section{Global patent data}

Another measure of global competitiveness is the trends and trajectories in patent filings. There are numerous sources of data, but for the purpose of this presentation was focused on Global data from the World Intellectual Property Office (WIPO) [22]. As listed in Table 4 China and the US accounted for the majority of worldwide Patent growth (80\%). China's IP growth more than doubled its GDP growth. Patent growth in Europe represented by France, Germany and the UK plus applications from the EPO far exceeded GDP growth rates. In addition, Japan displayed a patent growth that more than doubled GDP. In contrast, the Republic of Korea had the only reporting office where GDP growth exceeded patent growth.

Impact: IP growth patterns represent further indications of innovation and future strength. Once again, there are strong indications that China is incrementally increasing its competitiveness. However, within the IP domain the US and other established economies continue to display strong growth [22].

\section{Research metrics}

Analysis of research metrics permits an evaluation of both the number of papers contributed by researchers by country as well as the impact of these papers, as measured by the number of times cited in high impact journals.

Thomson Reuters provides coverage of global bibliometrics. Table 5 includes Essential Scientific Indicators from Thomson Reuters that shows that the USA remains the global leader by papers written by 
Table 5

ESI listings: By papers

\begin{tabular}{|l|l|r|r|r|}
\hline Rank & Country & Papers & Citations & Cites per paper \\
\hline 1 & USA & $3,049,662$ & $48,862,100$ & 16.02 \\
\hline 2 & Peoples R China & 836,255 & $5,191,358$ & 6.21 \\
\hline 3 & Germany & 784,316 & $10,518,133$ & 13.41 \\
\hline 4 & Japan & 771,548 & $8,084,145$ & 10.48 \\
\hline 5 & England & 697.763 & $10,508,202$ & 15.06 \\
\hline 6 & France & 557,322 & $7,007,693$ & 12.57 \\
\hline 7 & Canada & 451,588 & $6,019,195$ & 13,33 \\
\hline 8 & Italy & 429,301 & $5,151,675$ & 12,00 \\
\hline 9 & Spain & 339,154 & $3,588,655$ & 10.58 \\
\hline 10 & Australia & 304,160 & $3,681,595$ & 12.10 \\
\hline
\end{tabular}

Source: Thomson Reuters http://sciencewatch.com/dr/cou/2011/11decALL

Note: Colors are visible in the online version of the article; http://dx.doi.org/10.3233/ ISU-2012-0636.

Table 6

ESI listings: Sorted by citations

\begin{tabular}{|l|l|r|r|r|}
\hline Rank & Country & Papers & Citations & Cites per paper \\
\hline 1 & USA & $3,049,662$ & $48,862,100$ & 16.02 \\
\hline 2 & Germany & 784,316 & $10,518,133$ & 13.41 \\
\hline 3 & England & 697.763 & $10,508,202$ & 15.06 \\
\hline 4 & Japan & 771,548 & $8,084,145$ & 10.48 \\
\hline 5 & France & 557,322 & $7,007,693$ & 12.57 \\
\hline 6 & Canada & 451,588 & $6,019,195$ & 13,33 \\
\hline 7 & Peoples R & 836,255 & $5,191,358$ & 6.21 \\
\hline 8 & China & & & \\
\hline 9 & Italy & 429,301 & $5,151,675$ & 12,00 \\
\hline 10 & Australia & 304,160 & $3,681,595$ & 12.1 \\
\hline & Spain & 339,154 & $3,588,655$ & 10.58 \\
\hline
\end{tabular}

Source: Thomson Reuters

http://sciencewatch.com/dr/cou/2011/11decALL

Note: Colors are visible in the online version of the article; http://dx.doi.org/ 10.3233/ISU-2012-0636.

at least one author resident in the country followed by The Peoples Republic of China, Germany, Japan and the UK [16].

However, Table 6 illustrates that when the ranking is based on the number of citations, The US remains the clear leader, but China falls to the number seven position. The ranking by citations features Germany 
in the number two slot, followed by England, Japan, France and Canada [16]. For the most part, the difference between ranking by Papers and Citations leads to a discussion pitting the issue of quality vs. quantity. This is where another research series from Thomson Reuters leads to further understanding. The company has provided a series of Global Research Reports where a multi-dimensional assessment of various countries leads to a comprehensive understanding of the research profiles of various nations.

\section{Research profiles}

Thomson Reuters Global Research Reports have been developed to illustrate the patterns in scientific papers from selected nations. The following section reviews the findings from several of the recent Global Research Reports.

- The USA: Published in 2010 this Global Research Report concludes: "There is no longer the Colossus of Science, dominating the research landscape in its production of scientific papers, that it was 30 years ago. It now shares this realm on an increasingly equal basis, with the EU27 and AsiaPacific. In terms of relative citation impact - an indicator of utility, influence, significance and similar concepts - the US still holds a commanding but eroding peak position. Europe is beginning to match US performance in citation impact, and analysts are likely to be tempted to predict that, in a decade or two, Asian nations will do so as well" [13].

- China: The 2009 Global Research devoted to China states: "Beginning around the mid-1990s, China's output of scientific reports expanded dramatically, commencing a steep upward trajectory that has only increased in recent years. Figures covering the years 1999 to 2008, capture 'the increase in the annual number of Thomson Reuters-indexed papers featuring at least one author address in China. From just over 20,000 papers in 1998, China's output increased to upwards of 112,000 papers by 2008 - with the nation more than doubling its output since 2004 alone. By the measure of annual output, China surpassed Japan, the UK and Germany in 2006 and now stands second only to the USA" [17].

- Brazil: Another 2009 Global Research from Thomson Reuters states: "Brazil is an increasingly important and competitive research economy. Its research workforce capacity and R\&D investment are expanding rapidly, offering many new possibilities in a diversifying research portfolio. It has received much less policy attention than China, however, and the research base in Latin America in general is unfamiliar to many in Europe and Asia. The report shows that Brazil's output has doubled in ten years to 2007, part of a long-term trend of growth that far exceeds established G7 economies. Relative to the rest of the world, Brazil has exceptional capacity in biology-based disciplines and research related to natural resources" [10].

- India: A 2009 report from Thomson Reuters states, "In the modern era, science and technology have been central to India's development efforts since the nation achieved independence in 1947... Despite these achievements, recent years have seen a growing realization among scholars, policymakers, and other observers that India lags behind other key countries and some of its BRIC partners in research investment and output... A nagging problem, however - perhaps paradoxically for the second-most populous nation on earth - is a current lack of human resources: the availability of qualified researchers has not kept pace with the increased funding" [11].

- Japan: A 2010 Global Research Report from Thomson Reuters indicates: "Japan has a wellestablished research enterprise, world-class universities and government laboratories, and has produced a number of Nobel Prize winners. Yet its relative impact, across all fields taken together, 
remains below the world average. While its neighboring nations' citation impact is on the rise, Japan's numbers have lagged... In contrast to the scientific output of two surging Asian economies previously examined in these Global Research Reports - India and China - Japan's yield of research publications has been comparatively flat over the last decade" [12].

- The United Kingdom: A Thomson Reuters Global Research Report from October 2011 observes: "The UK spends $4 \%$ of the world's Gross Expenditure on R\&D on $6 \%$ of the worlds researchers who are authors on $8 \%$ of the world's research articles and reviews. These papers attract $11 \%$ of the world's citations and so create $14 \%$ of the world's highly cited output. Those exceptional articles include $17 \%$ of the world's research papers with more than 500 citations and $20 \%$ of those with more than 1000 citations. Its average research impact now surpasses that of the USA. Despite this outstanding performance - in terms of research efficiency, effectiveness and excellence - the level of private-sector research investment in the UK is surprisingly low and has fallen relative to comparators. The innovative capacity and potential of the UK is therefore not matched by its engagement with economic competitiveness, but this is not the fault of the research base" [14].

An expert from Thomson Reuters, Jonathan Adams, provided additional insights. He described some aspects of the research profiles of various countries. Elaborating on China Adams reported that:

- The numbers of papers from large regions make it "tricky" to appreciate change.

- He illustrated a view that is illustrated in Table 7 based on data that is indexed back to starting totals in 1981.

- The value of each region is set at 1.0 in 1981. Later years are compared back to that point.

- Each country is then tracked in terms of growth as a ratio.

- The USA grows more slowly than world average of the EU-27 does better.

- China accelerates past these, growing its published research output to more than 75 times the total in 1981 (135,000 articles in 2009 compared with 1750 1981).

- In some technology fields it already exceeds US output.

- In Chemistry it has grown 15 - fold and now produces 27,000 papers per year compared to 23,000 for the US.

- Initial signs of reaching a plateau - but growth in physical sciences is being mirrored by growth in biomedical and social sciences.

- "There is still, plenty of room for further expansion of the research portfolio" [15].

\section{Indicators of China's dramatic growth in research output}

Another interesting illustration is seen in Fig. 1. In this view there is a comparison with the level of un-cited papers; Cited papers normalized against relevant world average and most-cited papers for three countries: The USA $\sim 2,900,000$ papers; The UK $\sim 700,000$ papers; and China $\sim 500,000$ papers. As shown in Fig. 2, China has by far the most un-cited papers when compared with the other two countries. It also is lower when normalized against a relevant world average. However, when compared with the most cited papers, the graph lines between the three countries are very close. The conclusion to be drawn from Fig. 1 is that if most-cited papers are deemed as a measure of quality, China is demonstrating quality of research at the highest level in close proximity with the established US and UK. This view may be used to counter the notion that is often presented that China's increasing quantity of research lags in terms of quality [19]. 


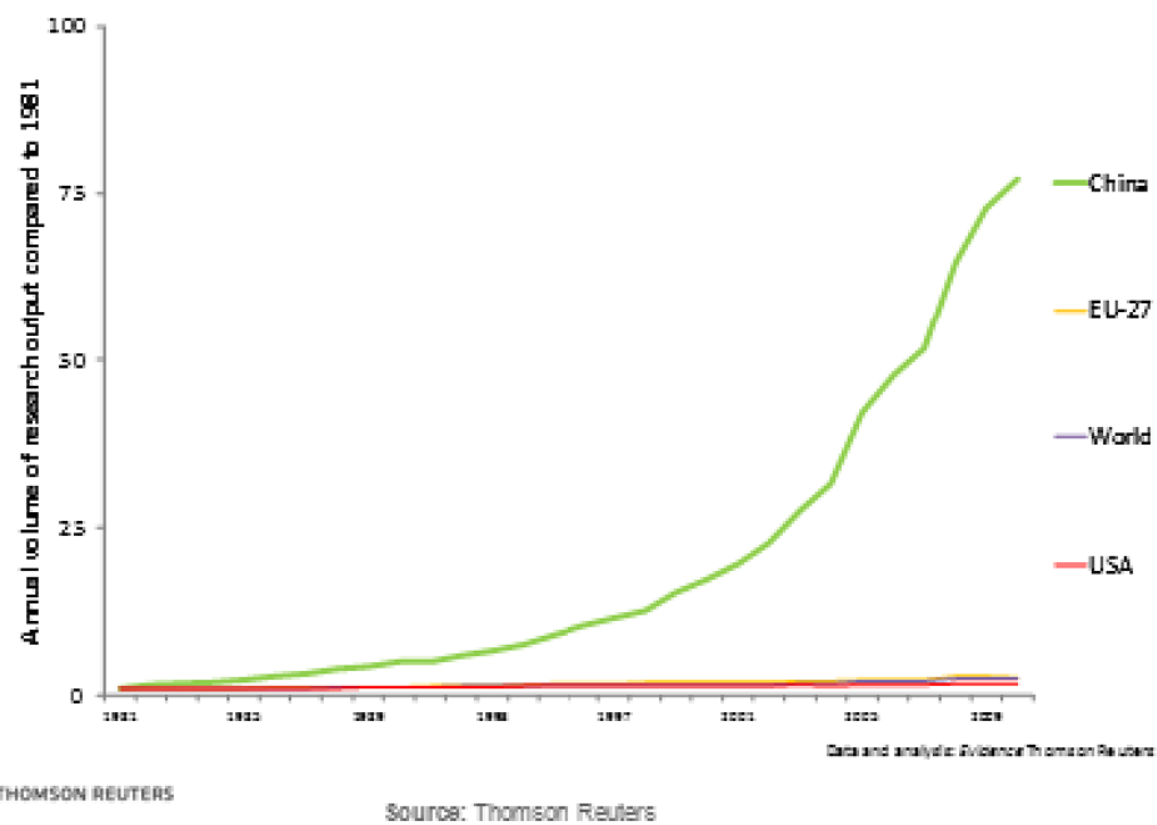

Fig. 1. China: Dramatic growth. (Colors are visible in the online version of the article; http://dx.doi.org/10.3233/ ISU-2012-0636.)

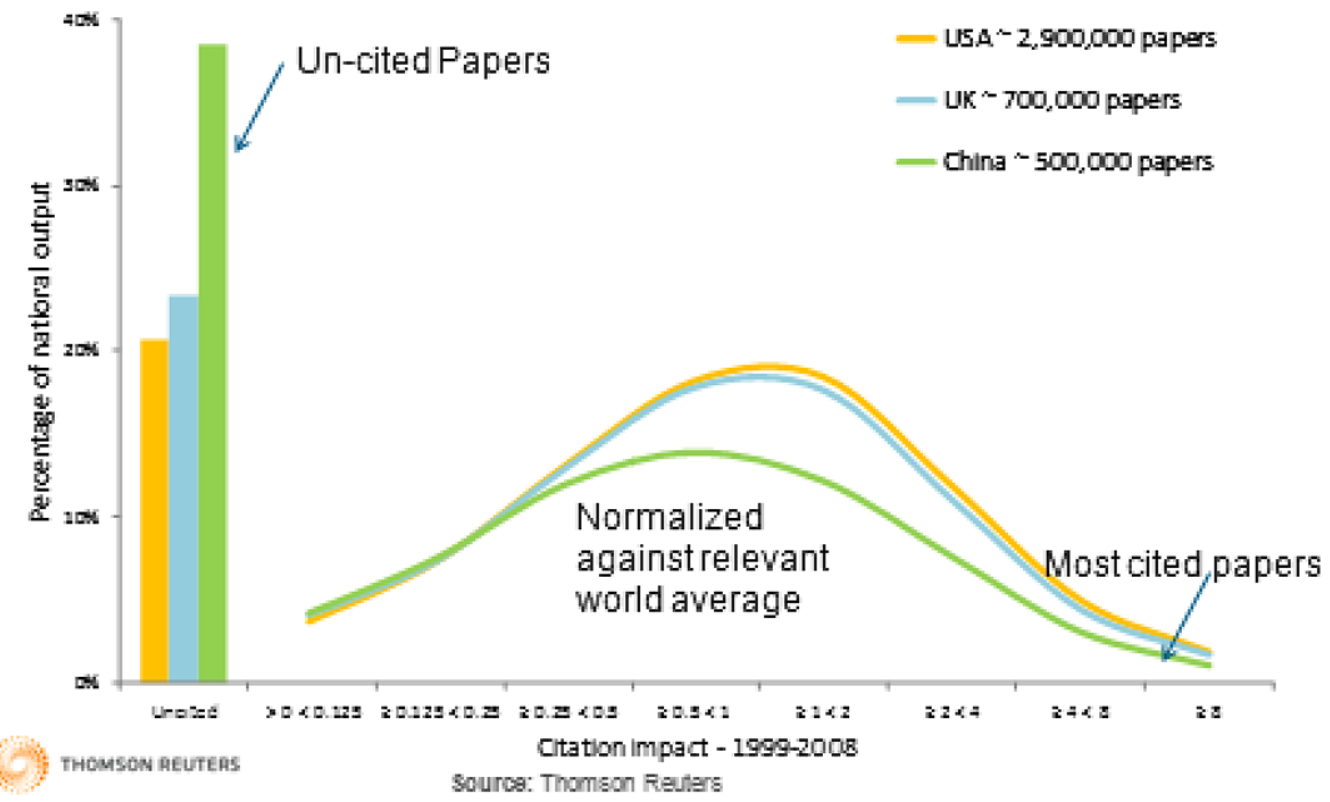

Fig. 2. Impact profile curves enable a rich comparison. (Colors are visible in the online version of the article; http://dx.doi.org/ 10.3233/ISU-2012-0636.)

The following section provides the latest view of significant Research Metrics based on data from Thomson Reuters [6]: 


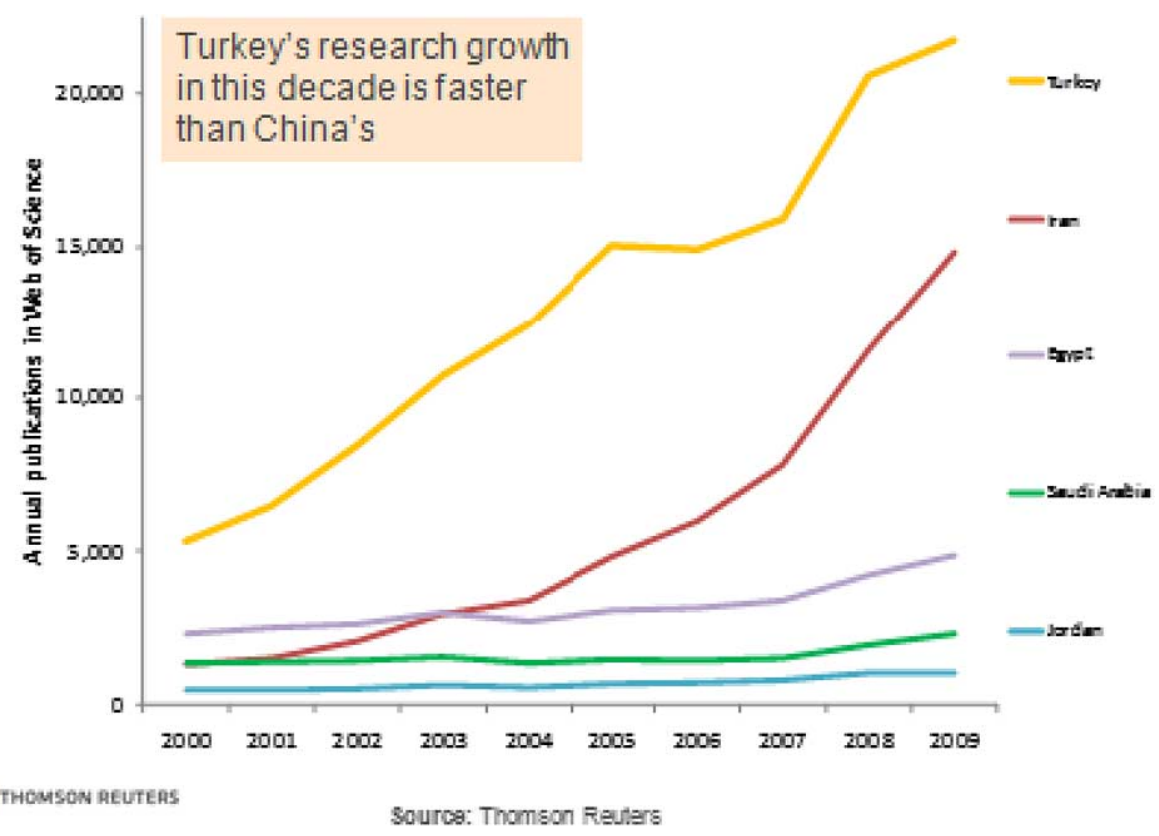

Fig. 3. The middle east is typical of new regional growth. (Colors are visible in the online version of the article; http://dx.doi.org/10.3233/ISU-2012-0636.)

- China:

- Plateau in growth in physical sciences and engineering but continued growth in biomedical sciences.

- Brazil:

- Growing in a different way to China because of its emphasis as a "natural knowledge" economy which may give it great sustainability.

- Research Metric Developments outside of the BRIC + Korea nations:

- Attention can be drawn to the following countries: Mexico, Egypt, Turkey and Poland as countries that have significant potential to be realized in the next ten years.

- Iran has a very dynamic research profile.

- Regionalization trends may be very important moving forward. For example the Asia-Pacific network could be very powerful; a Latin America network around a Brazil-Mexico axis should also emerge. This may then boost the status of regional journals, although the predominance of English as the common research language may constrain that potential [18].

- The Middle East is displaying the characteristics typical of new regional growth. For example Turkey's research growth in this decade is faster than China's as illustrated in Fig. 3.

\section{Global trends in global scholarship and the impact on STM publishers}

The increase in Scholarly Research within RDE's has been established by Thomson Reuters along with other sources of bibliometric analysis. A logical extension of this trend would be a change within 
the dynamics of STM publishing. However, based on a review of STM industry developments there is no evidence of a profound change to either the leadership or sustainability of the STM market. Rather, there appear to be new opportunities for legacy STM publishers to expand content offerings via partnering or increased coverage of research from the RDE's. In summary:

- There are notable multidimensional databases available in China that include access to Chinese STM journal articles, conferences and dissertations.

- In India STM publishers have forged local alliances and demonstrated interest via acquisition.

- Brazil is demonstrating an emerging STM publishing market, however the majority of focus appears to be within the book market.

China STM resources:

- CNKI: Chinese National Resource Infrastructure Database: Comprises four databases with coverage from 1994: Chinese Academic Journals Database (CAJ), China Core Newspaper Database (CCND), China Dissertations (CDMD) and China Conference Proceedings (CPCD). These databases may be searched for free. The CAJ Database includes over 9.5 million full text multidisciplinary articles from over 5000 serials title. The China Core Newspaper Database includes full text articles form newspapers from every province within China. The CDMD compiles full text Master's and Doctoral dissertations on all subjects from over 250 Chinese universities, colleges and institutes. These include the 211 Project universities selected by the Chinese government to receive special funding to support advanced research in crucial subjects. The China Conference Proceedings Database includes articles from conferences of over 340 national and international societies holding conferences in China [4].

- Wanfang: As an affiliate of the Chinese Ministry of Science \& Technology, Wanfang Data has been the leading information provider in China since the 1950s. It offers a wide range of database resources and value-added services. Wanfang Data has become a gateway to Chinese culture, medicine, business and science, etc. [21].

Table 7 summarizes highlights of the STM publishing market in India.

Table 7

Country-specific STM publishing markets: India

\begin{tabular}{|l|l|}
\hline Development & Description \\
\hline Notable Publishers: & $\begin{array}{l}\text { Global publishers with local operations including: Nature India; } \\
\text { Reed Elsevier; Sage Publications; Springer India; The Indian } \\
\text { Academy of Sciences (IAS); Thieme Medical Publishers Inc.; } \\
\text { Wiley India; McGrawOHill Professional India; MedKnow } \\
\text { Publications (acquired by Wolters Kluwer); }\end{array}$ \\
\hline $\begin{array}{l}\text { Notable India Based } \\
\text { Publisher }\end{array}$ & $\begin{array}{l}\text { CBS Publishers \& Distributors Pvt Ltd: CBS as an international } \\
\text { organization, now known for quality textbooks in medical } \\
\text { sciences and technology, and as the major source of } \\
\text { procurement of books, whether they are Indian, American } \\
\text { or European. }\end{array}$ \\
\hline Indian Citation Ineex & $\begin{array}{l}\text { The Indian Citation Index (ICI) database covers 1000 top Indian } \\
\text { scholarly journals encompassing all disciplines of knowledge }\end{array}$ \\
\hline
\end{tabular}

Source: STM Publishing in India, Heernet Ventures Limited, Sep 2011

Note: Colors are visible in the online version of the article; http://dx.doi.org/ 10.3233/ISU-2012-0636. 
Table 8

Brazil: STM publishing market

\begin{tabular}{|l|l|}
\hline \hline Market Dynamic & Commentary \\
\hline $\begin{array}{l}\text { Majority of STM } \\
\text { content focuses on } \\
\text { books }\end{array}$ & $\begin{array}{l}\text { STM Segment earned \$306M om 2009. } \\
\text { Major Players: }\end{array}$ \\
$\begin{array}{ll}\text { - Grupo Editorial Nacional Participacoes (GEN). GEN is the } \\
\text { market leader with \$62M (2009). It publishes technical books. } \\
\text { - Grupo A Editoras: Created by the Artmed publishing house in } \\
2010 \text { is an umbrella for several imprings: McGraw-Hill } \\
\text { Interamericana de Brasil, Artmed Editoria, Bookman, Tekne, } \\
\text { Artes Medicas and Penso. }\end{array}$ \\
$\begin{array}{l}\text { Journal Coverage } \\
\text { SciELO (Scientific Electronic Library Online) is open access } \\
\text { Latin American bibliographic database with 638 scientific } \\
\text { journals in full-text. 251 titles are from Brazil } \\
\text { Brazil has no established commercial STM journal publishing } \\
\text { industry, though several international publishers have a } \\
\text { substantial presence in Brazil." These include Elsevier, } \\
\text { Springer and Brazilian Physical Society. }\end{array}$
\end{tabular}

Source: Outsell, Brazillian STM Publishing on the Wax, June 5, 2011

Note: Colors are visible in the online version of the article; http://dx.doi.org/ 10.3233/ISU-2012-0636.

Table 8 focuses on the STM market in Brazil.

Overall, when recent STM publisher announcements were reviewed it appeared that rather than facing competitive markets, the publishers are following a path of partnering with local organizations or setting up regional brands within their core specialties. Table 9 provides a summary of publisher announcements that illustrate recent developments within regionally developing economies.

\section{Conclusion}

Based on a review of notable indicators and rankings covering a variety of categories it is safe to state that some nations of the world are indeed becoming more competitive. Recent trends indicate that established economies that have for many years led in various metrics are facing increasing levels of competition from Regionally Developing Economies. Among the fast developing economies China is displaying strong growth in various vectors, including GDP, Research Metrics and Academic achievement. However, certain smaller established economies, especially within the Nordic region such as Switzerland, Sweden, Finland and Denmark are ranking in the top spots when the evaluation is based on a complex series of Pillars and sub-Pillars that measure enabling capabilities and actual outputs or achievements. Switzerland, long considered to be a nation of great wealth has assumed the lead ranking in both the Global Innovation Index and the World Economic Forum Global Competitive Analysis. In addition, "efficiency" based on formulas permit smaller nations to lead in categories that illustrate efficient utilization of available resources.

Meanwhile, the US, although spending heavily on R\&D, increasing patent production, strong research metrics along continued increases in educational enrollments has lost the top position within the GII and faces increased competition within GDP where the US traditionally leads. There are forecasts that China will assume the number one spot as soon as 2016.

Moving forward the changes within global competitiveness assessments should have an increasing impact on global trade and commerce, scientific discovery, and overall quality of life, when discovery 
Table 9

Summary of publisher announcements

\begin{tabular}{|c|c|}
\hline Development & Description \\
\hline IET and INASP & $\begin{array}{l}\text { Agreement to provide certain developing and emerging countries within Africa, Asia and } \\
\text { Latin America access to IET Research and Letters Journals. The result is that users in } \\
\text { selected regions are able to gain access to IET resources and other scientific information } \\
\text { free of charge or at significantly reduced cost. }\end{array}$ \\
\hline ProQuest & $\begin{array}{l}\text { Will distribute SIAM (Society for Industry and Applied Mathematics) to libraries world- } \\
\text { wide. }\end{array}$ \\
\hline Knovel & Expands partner ecosystem with six new global publishing partners. \\
\hline NPG & Announces open access for Japanese Titles. \\
\hline Swets & $\begin{array}{l}\text { Libraries R-evolution project now contains contributions from over } 70 \text { of Asia's dis- } \\
\text { tinguished libraries and institutions; Swets announced sales and marketing partnership } \\
\text { with Wisers, a Hong Kong-based China news information provider. }\end{array}$ \\
\hline Springer & $\begin{array}{l}\text { Partners with Edanz Group, editing service for international authors who's first language } \\
\text { is not English. }\end{array}$ \\
\hline Thomson Reuters & $\begin{array}{l}\text { Web of Knowledge selected by Conseo Nacional de Cliencia Y Technologia } \\
\text { (CONACYT), a national council promoting science and technologies polices in Mex- } \\
\text { ico, to enhance the research and analytic capabilities of researchers across Mexico. }\end{array}$ \\
\hline ProQuest Serials Solution Summon & $\begin{array}{l}\text { Selected by Peking University in China to improve the discoverability and usability of } \\
\text { a vast collection of digital resources and materials. Peking University claims to serve } \\
\text { more than } 45,000 \text { students. }\end{array}$ \\
\hline Wolters Kluwer & Acquired India-based OA STM publisher MedKnow. \\
\hline UK & $\begin{array}{l}\text { UK research faces challenge from emerging according to The Assn. of the British Phar- } \\
\text { maceutical Industry (ABPI). ABP warned that the UK must continue to attract invest- } \\
\text { ment for research, or risk being surpassed by emerging markets. }\end{array}$ \\
\hline McGraw-Hill & McGraw-Hill and Wipro will develop mobile learning platform for emerging markets. \\
\hline Elsevier & $\begin{array}{l}\text { Bilingual publications to enhance medical education in the Middle East; Elsevier has } \\
\text { collaborated with Tsinghua University Department of Computer Science and Technol- } \\
\text { ogy in Beijing to introduce four new research productivity enhancing applications for } \\
\text { SciVerse Applications. }\end{array}$ \\
\hline Gale & Introduces Gale World Scholar: Latin America and the Caribbean. \\
\hline Springer & In deal with Dai Nippon Printing for POD solutions in Japan. \\
\hline Thomson Reuters & $\begin{array}{l}\text { InCites selected by the South Africa National Research Foundation to analyze institu- } \\
\text { tional productivity. }\end{array}$ \\
\hline \multirow[t]{2}{*}{ Springer } & $\begin{array}{l}\text { Springer and Asia Briefing announced ePublishing agreement to enhance business and } \\
\text { management book programs. The agreement is for technical and business guides. }\end{array}$ \\
\hline & $\begin{array}{l}\text { Springer also announced that the University of Hong Kong Libraries has signed a re- } \\
\text { newal agreement that allows researchers with affiliation to the HKU to publish their } \\
\text { research results in Springer journals using Springer Open Choice. }\end{array}$ \\
\hline NPG & $\begin{array}{l}\text { NPG expanded an open access publishing in China. Under the initiative, NPG will pub- } \\
\text { lish two open access journals } 0 \text { International Journal of Oral Science and Light Sci- } \\
\text { ence \& Applications - with Chinese universities from } 2012 \text {. }\end{array}$ \\
\hline
\end{tabular}

Source: Various publisher announcements.

and scholarship are used for peaceful objectives. However, a key challenge to both the growing and established economies will be "sustainability". The established economies will have the opportunity to improve on those metrics that have lowered overall position, while the up and coming economies will need to demonstrate that growth and efficiency will be sustained. It will be important to monitor future editions of the data cited within the report to see if current patterns will continue. 


\section{References}

[1] 2012 Global R\&D Funding Forecast, Battelle and R\&D Magazine, December 2011.

[2] R.J. Barro and J.-W. Lee, A new Data Set of Educational Attainment in the World, 1950-2010, available at: http://www.nber. org/papers/w15902.

[3] Business Dictionary.com, available at: http://www.businessdictionary.com/definition/gross-domestic-product-GDP.html.

[4] CNKI, http://eng.cnki.net/grid2008/index.htm.

[5] India: The next university superpower?, Mar 2011, UNESCO.

[6] Information provided by Jonathan Adams, FRSA, Director of Research \& Development, Thomson Reuters, IP\&S.

[7] National Science Board, Science and Engineering Indicators 2010.

[8] OECD, Frascati Manual, Proposed Standard Practice for Surveys on Research and Experimental Development, 2002.

[9] The Global Innovation Index 2011, Accelerating Growth and Development, INSEAD, 2011.

[10] Thomson Reuters, Global Research Report, Brazil, June 2009.

[11] Thomson Reuters, Global Research Report, India, October 2009.

[12] Thomson Reuters, Global Research Report, Japan, June 2010.

[13] Thomson Reuters, Global Research Report, United States, November 2010.

[14] Thomson Reuters, Global Research Report, United Kingdom, October 2011.

[15] Thomson Reuters, Data and analysis: Evidence Thomson Reuters, 2012.

[16] Thomson Reuters, http://sciencewatch.com/dr/cou/2011/11decALL.

[17] Thomson Reuters, Global Research Report, China, November 2009.

[18] Thomson Reuters, 2012.

[19] Thomson Reuters Citation impact 1999-2008, Thomson Reuters, 2009.

[20] US National Science Foundation, Higher Education in Science \& Engineering, 2012, Chapter 2.

[21] Wanfang, http://www.wanfangdata.com/.

[22] WIPO, 2011 World Intellectual Property Indicators.

[23] World Economic Forum, The Global Competitiveness Report 2011-2012. World Economic Forum, Geneva Switzerland, September 2012. 